\title{
Global Markets and Development Policies in Large-Scale Retailers
}

\author{
Sabina Riboldazzi*
}

\begin{abstract}
In recent years, large-scale retailers have found ways to overcome the emergence of increasingly severe constraints on retail business development by devising new development trajectories aimed at maintaining or strengthening their competitive positions. In this report, we analyse the operating activities of some of the major global and Italian large-scale retailers, ranked by revenue, with special emphasis on the following aspects: 1) basic common development policies that have been implemented over time by companies to improve their competitiveness; 2) new common development policies adopted by retailers in recent years as countermeasures against growth constraints characterising most of the retail markets where they operate.
\end{abstract}

Keywords: Large-Scale Retailers; Development Policies; Growth Constraints; Global Markets

\section{Global Markets and Development Policies in Large-Scale Retailers}

In the last decade, large-scale retail markets, particularly those in countries most affected by the recent economic crisis, have been characterised by intense competition, volatile demand, fluctuating consumption, increasing of corporate promotional pressure, and reduction of first-level trade margins. The discontinuity, complexity, and instability of the global market has forced large-scale retailers to reconsider their development policies with regard to resource waste, temporarymarket opportunities and customer satisfaction while at the same time reconciling all the different stakeholders' interests to improve or maintain their competitiveness. In particular, retailers competing in today's global market have originated from different backgrounds and have developed in different way and at different time in relation to changes taking place in the retail distribution sector in each specific geographical area. Indeed, the birth of modern retail distribution occurred first in the US during the interwar period. In particular, in 1930, in the wake of the economic crisis of 1929, Michal Cullen opened the first self-service supermarket. A few years later, fifteen King Kullen stores were opened to the public, thereby becoming the first supermarket chain in the US, characterised by low prices and reduced profit margins, but capable of generating higher sales volumes than ever before. In Europe, the gradual transition from traditional sales forms to modern distribution took place in the UK after the Second World War for instance, in 1950, Sainsbury's managed to convert one of its stores located in

\footnotetext{
* Assistant Professor of Management, University of Milan-Bicocca (sabina.riboldazzi@unimib.it)
}

Edited by: ISTEI - University of Milan-Bicocca

ISSN: $1593-0319$

Riboldazzi, S. (2015). Global Markets and Development Policies in Large-Scale Retailers, Symphonya. Emerging Issues in Management (symphonya.unimib.it), 5, 8-28. 
London Road, Croydon, into a 300 square-meter self-service store. Later on, in 1955, the first 700 square-meter store was unveiled in Lewisham. In 1957, Nelson Rockfeller opened the first Italian supermarket in Milan, named Supermarket Italiani Spa. However, it was not until the 1980s that the modernisation of the Italian distribution system began, leading to a gradual reduction of traditional retail stores over a twenty-year period. In this regard, the significant delay in this innovation process has ultimately hampered the ability of large-scale Italian retailers to play a relevant role among top-ranking European and global retailers.

Table 1: The Main Large-Scale Retailers/Wholesalers in Global Markets. Revenues in 2015 (Billion $€$ )

\begin{tabular}{|c|c|}
\hline Company & Revenues \\
\hline Walmart & 467 \\
\hline Costco & 114 \\
\hline Carrefour & 109 \\
\hline Kroger & 104 \\
\hline Tesco & 96 \\
\hline Walgreens & 94 \\
\hline Schwarz Group & 92 \\
\hline Seven \& I & 91 \\
\hline Aldi & 80 \\
\hline Metro Group & 72 \\
\hline
\end{tabular}

Source: Planet Retail, 2015.

Table 2: The Main Large-Scale Retailers in the Italian Market. Market share in 2015

\begin{tabular}{|c|c|}
\hline Company & Market Share \% \\
\hline Coop Italia & 14.5 \\
\hline Conad & 11.9 \\
\hline Selex & 9.7 \\
\hline Esselunga & 8.9 \\
\hline Auchan & 6.7 \\
\hline Carrefour & 6.1 \\
\hline Eurospin & 5.1 \\
\hline Vege & 3.4 \\
\hline Pam & 3 \\
\hline Finiper & 2.8 \\
\hline Lidl & 2.7 \\
\hline Agorà & 2.5 \\
\hline Sun & 2.5 \\
\hline Lillo & 2.3 \\
\hline Aspiag & 2.2 \\
\hline Crai & 2.2 \\
\hline Sigma & 2.2 \\
\hline Sisa & 2 \\
\hline \multicolumn{2}{|c|}{$\begin{array}{l}\text { Others }(<2) \text { : Bennet 1.9, C3 1.5, Rewe } \\
\text { 1.3, Despar 1.2, Cat. Ind 1.1, Neg. Ind. } 1 \text {, } \\
\text { Tuo 0.9, Cds Spa 0.2, Coralis 0.2. }\end{array}$} \\
\hline
\end{tabular}

Source: Conad Annual Report, 2015. 
Nevertheless, the development of Italian large-scale retailers, albeit of a modest entity and with some delay, has followed the same path as other European and global goods distributors. In particular, when we consider the main development policies implemented by large-scale retailers over time (Figure 1), we can find common features with reference to points of sale, format, and reference market, hence, the selection of specific product/market combinations. Specifically, we define product as the commercial service or the store which is made up of a "set of features" such as its assortment, access services, and pre-, during-, and post-sale services. Indeed, each specific feature combination gives rise to different distributive form (i.e. format, such as supermarkets, superstores, discount stores, etc.). Furthermore, we define market as "commodity sector or market segment" when the company expands its business in geographical areas where it is already physically present. Alternatively, we define market as "spatial market" when the company develops new stores in geographical areas where it was not previously present. In this case new stores may contemplate modifications with reference to commodity sector or market segment.

Figure 1: The Main Development Policies in Large-Scale Retailers

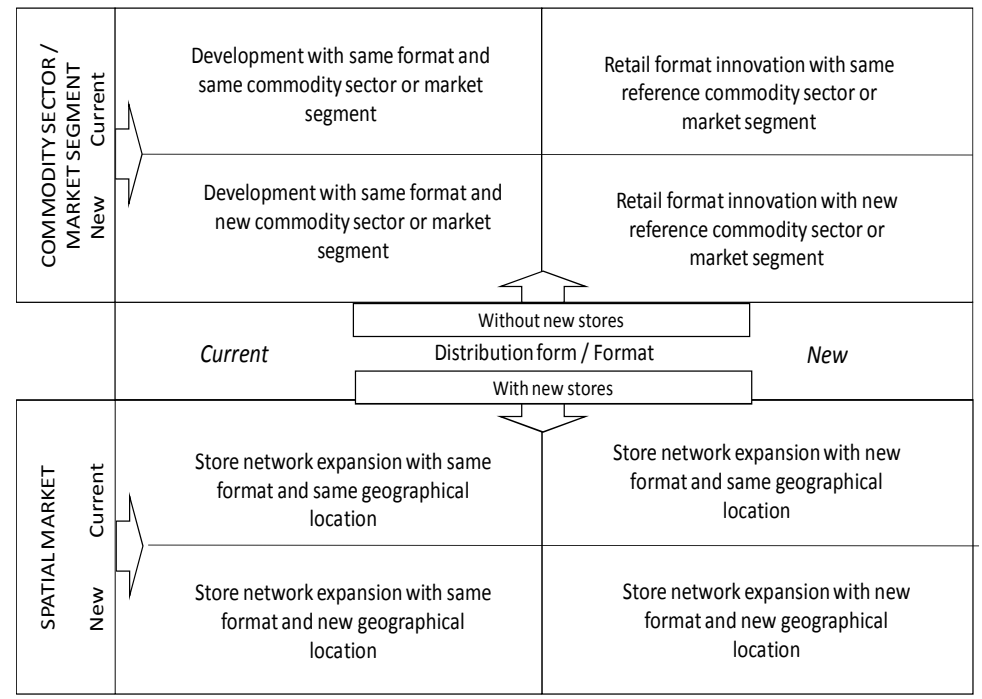

Source: Author's elaboration

We can then sum up the main basic common development policies activated by large-scale retailers as follows:

1. Development with same format and same commodity sector or market segment. In this case, business growth is achieved thanks to an increase in sales per customers (average receipt amount) or in purchase frequency. This strategic direction is characterised by effective retailing mix management (i.e. assortment, private label, communication/advertising, merchandising, and price).

2. Development with same format and new commodity sector or market segment. In this case, the growth process consists in changing the retailer's segment market without altering its retail format or commercial service. Thus, 
development is often associated with changes in the product range (e.g. from women's to men's clothing).

3. Retail format innovation with same reference commodity sector or market segment, that is to say developing a new format by modifying slightly some of its basic services and features (e.g. conversion of a traditional grocery store into a minimarket, which offers a different product and service range while maintaining the same commodity sector or market segment).

4. Retail format innovation with new commodity sector or market segment. In this case, business development is pursued by changing the reference commodity sector as well as the customer service and the retail format, e.g. changing a medium size specialised store selling children's toys into a larger size specialised store selling adults' apparel.

5. The four above-mentioned development options represent a process of change and adaptation of the company, which usually does not lead to company's size growth (e.g. opening of new retail shops), because the innovation process itself takes place in existing stores. In contrast, the four development options described below, which rely on the opening of new stores, result in company's size growth. This, in turn, can lead to cost advantages thanks to the achievement of significant economies of scale, scope, and sharing:

6. Store network expansion with same format and same geographical location. This occurs when a company operates in geographical areas with a high potential demand, not yet exploited. Thus, the company's market share and competitiveness can be improved by just opening new retail stores with same services and formats as the existing ones, in the same geographical area.

7. Store network expansion with same format and new geographical location. The company growth occurs thanks to the opening of new stores in new markets keeping the same format used in other geographical areas. Development occurs thanks to the fulfilment of consumer demands in different geographical locations, combined with the benefits brought by dimensional economies.

8. Store network expansion with new format and same geographical location. It involves the development of new business activities by combining existing stores with new stores, in terms of product range and services, offering for example complementary products to exploit sales and geographical location synergies.

9. Store network expansion with new formats and new geographical location. It consists in the opening of stores with new retail formats in new geographical areas. It is a diversified development often obtained thanks to the creation of competitive and strategic alliances and the use of advanced management skills.

\section{Global Markets, Growth Constraints, and Development Policies in Large-} Scale Retailers

Over the last few years, modern large-scale retailers have had to counteract the emergence of new growth constraints by devising new business development policies particularly focused on reducing costs, meeting an ever changing consumer 
demand, and identifying sudden market opportunities, which otherwise would be exploited by competitors.

Some constraints affecting large-scale grocery retailers are as follows:

- a progressive market saturation due to the fast-paced development of modern retail in some areas, especially over the last three decades;

- a change in consumer demand from the standpoint of quantity (e.g. birth rate reduction in some areas) as well as quality (e.g. demand changes due to age segments or family profiles);

- a growing rationality in consumer buying behaviour, which runs up against choice overload, i.e. the exponential increase in options of consumer spending;

- a strong emphasis on vertical as well as horizontal competition dynamics, together with a gradual and significant increase in corporate promotional pressure and shelf price deflation resulting in progressive profit margin contraction.

In this new scenario, companies have been trying to optimise product, process and organisational innovation in order to become more efficient, effective, and competitive. This optimisation process, common to all large-scale retailers analysed in this study, qualifies the "new development policies" adopted by retailers in recent year:

\subsection{Improvement of Business Function Efficiency}

Retail companies output clearly depends on effective management of business functions, i.e. the series of activities necessary to ensure proper delivery of goods to the stores so that the retailers can offer a commercial service characterised by a unique set of features. Besides the main functions of transport, storage, assortment, and communication, retailers have to manage many other functions related to different services (e.g. pre-, during-, and post-sale), which constitute the backbone of their product portfolio.

In today's scenario, large-scale retailers have to operate according to the principles of timeliness, specialisation, and high volumes, in order to achieve dimensional economies, reduce costs, and improve the efficiency of their business functions.

In this regard, large-scale retailers often form partnerships and alliances (mergers and acquisitions, joint venture, franchising, etc.) (Tables 3, 4) and employ new technologies to carry out their activities.

Indeed, procurement, storage, transport or other activities are often managed together with several partners (e.g. competitors, suppliers, etc.), specialised and/or with the necessary expertise to operate and quickly gain a competitive advantage in specific geographical locations. For instance, with regard to procurement, the majority of retailers join buying groups where they can pool their buying power in order to negotiate better prices and payment terms with suppliers (Table 4). 
Table 3: Stores and some Alliances ${ }^{l}$ of the three Largest Global Retailers Ranked by Revenue

\begin{tabular}{|c|c|c|}
\hline & $\begin{array}{c}\text { Stores - years } \\
2014,2013,2012\end{array}$ & Birth and Some Alliances \\
\hline Walmart & $\begin{array}{l}\text { Year 2014: } 4,835 \\
\text { stores in United } \\
\text { States and } 6,107 \\
\text { international } \\
\text { stores. } \\
\text { Year 2013: } 4,625 \\
\text { stores in United } \\
\text { States and } 6,148 \\
\text { international } \\
\text { stores. } \\
\text { Year 2012: } 4,479 \\
\text { stores in United } \\
\text { States and 5,651 } \\
\text { international } \\
\text { stores. }\end{array}$ & $\begin{array}{l}\text { In } 1962 \text { Sam Walton opened the first Walmart store in Rogers, Ark. The company } \\
\text { rapidly developed its activities, first in America and then, through } \\
\text { mergers/acquisitions, joint ventures and numerous equity and non-equity alliances } \\
\text { with several specialised operators, outside America's borders. Here are some } \\
\text { milestones: in 1991, through a joint venture with Cifra, a Mexican retail company, } \\
\text { Walmart went global, opening a Sam's Club in Mexico City; in 1994, the company } \\
\text { expanded into Canada with the purchase of } 122 \text { Woolco stores; in 1998, Walmart } \\
\text { entered the United Kingdom with the acquisition of ASDA; in 2002, Walmart } \\
\text { entered the Japanese market through its investment in Seiyu; in 2009, Walmart } \\
\text { entered Chile with the acquisition of a majority stake in D\&S S.A.; in 2010, Bharti } \\
\text { Walmart, a joint venture, opened its first store in India; in 2011, with the acquisition } \\
\text { of MassMart in South Africa, the company surpassed 10,000 retail units around the } \\
\text { world; in 2013, the company acquired Bharti Walmart Private Limited, including } \\
\text { the Best Price Modern Wholesale cash and carry business in India; in 2015, } \\
\text { Walmart acquired 100\% stake in Yihaodian, an e-commerce business in China } \\
\text { (http://www.walmart.com/). }\end{array}$ \\
\hline Carrefour & $\begin{array}{l}\text { Year 2013: } 10,105 \\
\text { stores in } 34 \\
\text { countries. } \\
\text { Year 2012: } \\
9,994 \text { stores in } 33 \\
\text { countries. }\end{array}$ & 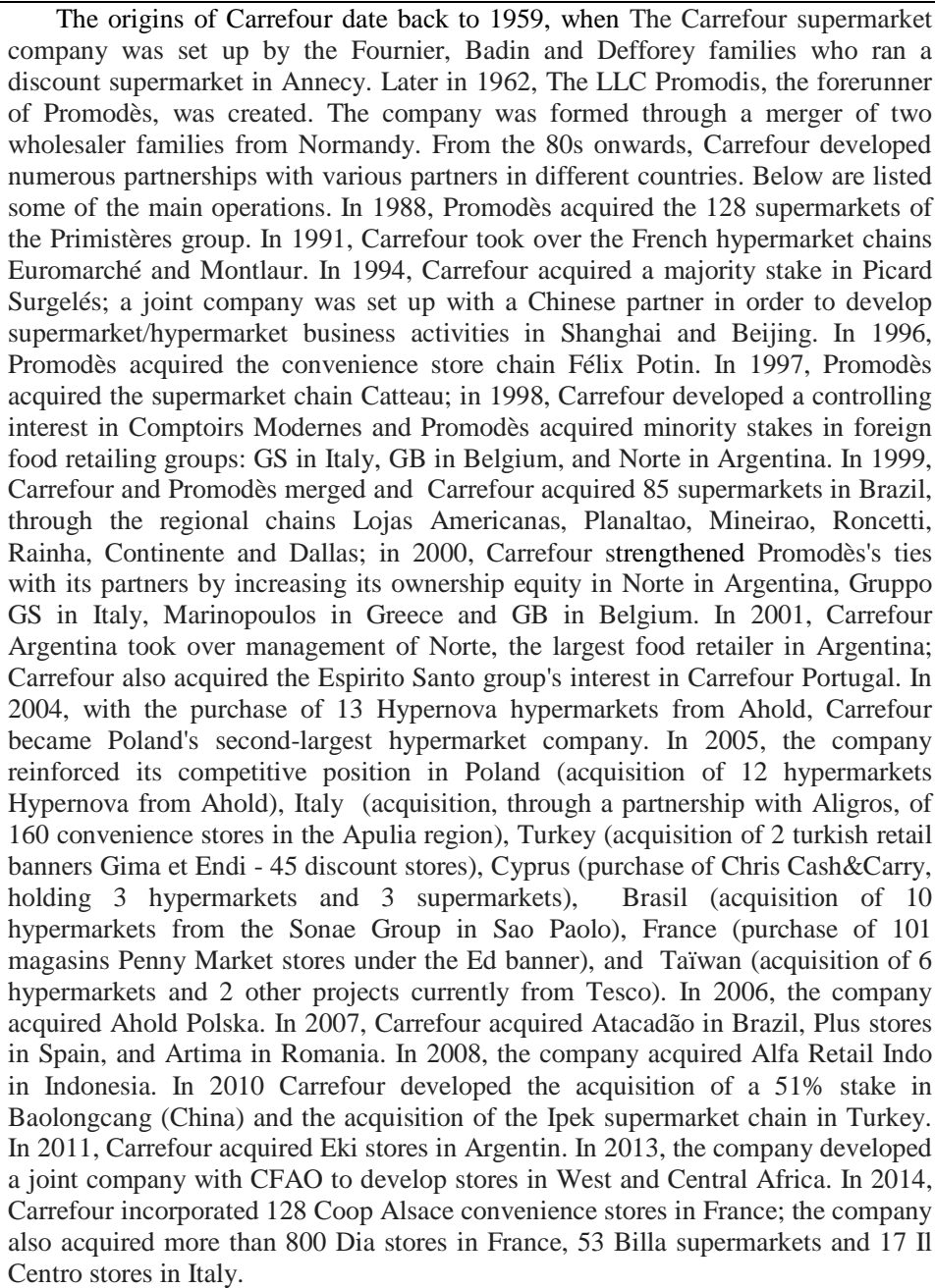 \\
\hline Kroger & $\begin{array}{l}\text { Year 2014: } 2,625 \\
\text { supermarkets in } \\
34 \text { US States and } \\
\text { The District of } \\
\text { Columbia, } 782 \\
\text { Convenience }\end{array}$ & $\begin{array}{l}\text { Kroger's history dates back to } 1883 \text { when Barney opened a grocery store at } 66 \\
\text { Pearl Street in downtown Cincinnati. Mergers have played a key role in Kroger's } \\
\text { growth over the years. In } 1983 \text { Kroger merged with Dillon Companies Inc. in } \\
\text { Kansas to become a coast-to-coast operator of food, drug and convenience stores. } \\
\text { Furthermore the biggest merger of Kroger took place in 1999, when the company } \\
\text { teamed up with Fred Meyer, Inc. in a } \$ 13 \text { billion deal that created a supermarket }\end{array}$ \\
\hline
\end{tabular}




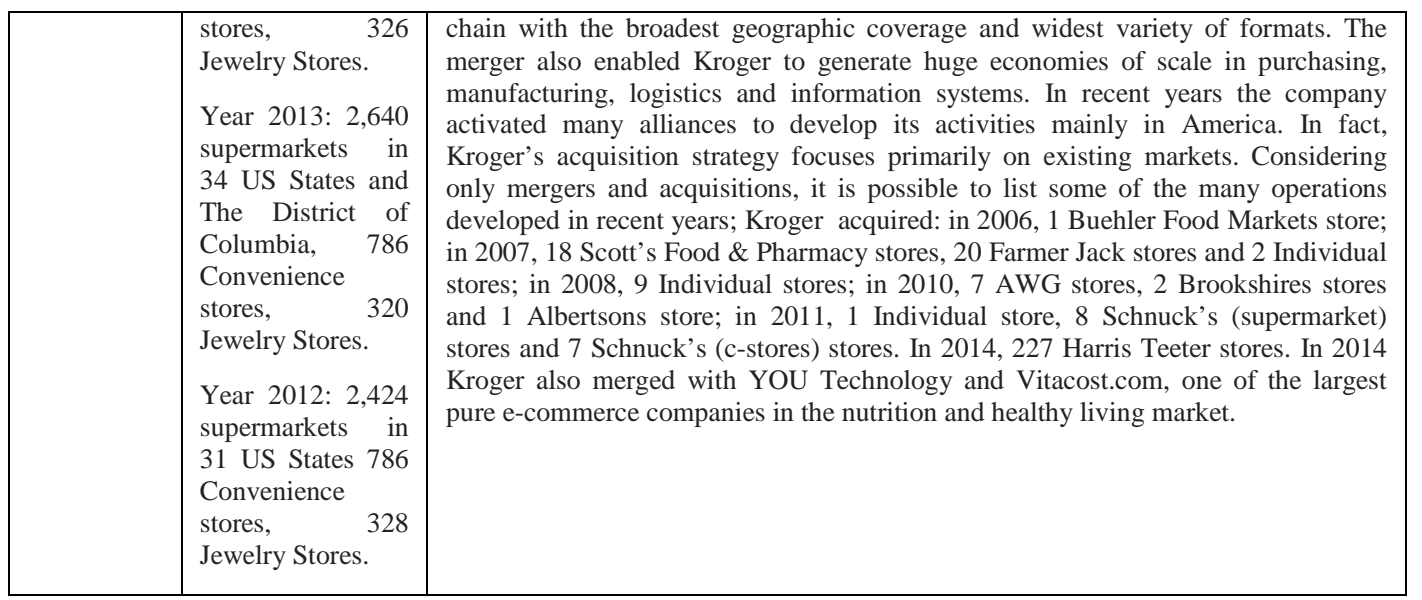

Source: Walmart Annual Report, 2012, 2013, 2014; ASDA, Our business @ Asda, October 7, 2013; Carrefour, Annual Activity and Responsible Commitment Report 2012, 2013, 2014; Kroger, The Kroger Co. Fact Book, 2012, 2013, 2014.

Table 4: Stores and Some Alliances ${ }^{2}$ of the three Largest Italian Retailers Ranked by Revenue

\begin{tabular}{|c|c|c|}
\hline & $\begin{array}{l}\text { Stores - years } \\
2014,2013 \text {, } \\
2012\end{array}$ & Birth and Some Alliances \\
\hline Coop & $\begin{array}{l}\text { Year 2014: } \\
\text { 1,189 stores } \\
\text { Year 2013: } \\
\text { 1,199 stores } \\
\text { Year 2012: } \\
\text { 1,467 stores }\end{array}$ & $\begin{array}{l}\text { In Italy, the consumer cooperative movement was born in } 1854 \text { in Turin. Today, } \\
\text { Coop groups } 97 \text { cooperatives, of which } 9 \text { are big companies, } 12 \text { medium-sised } \\
\text { companies and all the rest are small companies, operating in line with a value system } \\
\text { identical to the one of the first consumer cooperative established in } 1844 \text { in Rochdale, } \\
\text { England, by a group of "Principled pioneers" who shared the goal of "improving } \\
\text { economic and social situation of its members". After participating in Italia } \\
\text { Distribuzione (buying centre joined by Coop and Conad as well) } \\
\text { (http://www.conad.it/conad/home.html), in 2005, Coop allied with Sigma and } \\
\text { developed Centrale Italiana, a buying centre joined later by Despar, Il Gigante, and } \\
\text { Disco Verde. } \\
\text { After the termination of Centrale Italiana, in 2014, Coop allied with Coopernic, a } \\
\text { European buying centre, joined also by Leclerc, and Delhaize. The agreement included, } \\
\text { among its main goals: the optimisation of business conditions with international } \\
\text { suppliers; the research for synergies to improve product offer to consumers; and the } \\
\text { improvement of private label production (Coop, Undicesimo Rapporto Sociale } \\
\text { Nazionale della Cooperazione di Consumatori, 2014). }\end{array}$ \\
\hline Conad & $\begin{array}{l}\text { Year 2014: } \\
\text { 3,015 stores } \\
\text { Year 2013: } \\
\text { 3,019 stores } \\
\text { Year 2012: } \\
\text { 3,067 stores }\end{array}$ & $\begin{array}{l}\text { Conad was founded in } 1962 \text { following the aggregation of } 14 \text { buying groups led by } \\
420 \text { retailer members from Consorzio Nazionale Dettaglianti, a cooperative limited } \\
\text { company. Today Conad aggregates } 8 \text { big cooperatives, which count a total of } 2,722 \\
\text { associated retailers. } \\
\text { In } 1993 \text {, Conad, together with Sigma and Conitcoop, founded Sicon. Seven years later, } \\
\text { Italia Distribuzione, which currently is not active any longer, was created thanks to the } \\
\text { alliance between Conad and Coop, becoming a common centre of negotiation with the } \\
\text { brand industry. In 2004, the company allied with Rewe Italia and in 2006, Conad, } \\
\text { Colruyt (Belgium), Coop (Switzerland), E.Leclerc (France) and Rewe (Germany) } \\
\text { founded Coopernic, a buying centre later left by Conad, in Bruxelles } \\
\text { (http://www.conad.it/conad/home.html) In 2014, Conad participated in the European } \\
\text { buying centre Core Alliance made of four big European retailer groups - Conad, } \\
\text { Colruyt (Belgium), Coop (Switzerland) and Rewe (Germany) - which shared their } \\
\text { know-how on branded industry products and on private label products, negotiating } \\
\text { jointly with international suppliers (Conad, Annual Report, 2014). In 2015, Conad } \\
\text { promoted the AgeCore agreement, an international strategic alliance which grouped } \\
\text { together Core Alliance and Alidis partners (Alliance internationale de distributeurs). } \\
\text { Besides Conad, also Swiss Coop, Belgian Colruyt, German Edeka, French Groupement } \\
\text { des Mousquetaires and Spanish Eroski participate currently in the coalition (Conad, } \\
\text { Annual Report, 2015). }\end{array}$ \\
\hline Selex & $\begin{array}{l}\text { Year 2014: } \\
\text { 2,549 stores (of } \\
\text { which } 90 \text { Cash } \\
\text { and Carry) }\end{array}$ & $\begin{array}{l}\text { Selex origins date back to } 1964 \text {, when a group of grocery wholesalers established } \\
\text { the Italian voluntary union called A\&O; over a few years, its members increased and } \\
\text { became retail centers. The voluntary union became the Italian Consortium A\&O, } \\
\text { which, in 1979, founded Selex Gruppo Commerciale (http://www.selexgc.it/). }\end{array}$ \\
\hline
\end{tabular}




\begin{tabular}{|l|l|l|}
\hline $\begin{array}{l}\text { Year 2013: } \\
\text { 2,563 stores (of } \\
\text { which 88 Cash } \\
\text { and Carry) }\end{array}$ & $\begin{array}{l}\text { Currently, Selex is affiliated to domestic brands Famila, A\&O and C+C, besides 20 } \\
\text { other brands operating in different Italian regions. Companies allied with Selex Gruppo } \\
\text { Commerciale rely on the centre for commercial/marketing activities, development of } \\
\text { private label products and group activities included in the corporate social } \\
\text { responsibility. Moreover, the centre improves negotiations in Esd Italia and Emd }\end{array}$ \\
$\begin{array}{l}\text { Year 2012: } \\
\text { Europe. Indeed, in 2001, Selex created with Esselunga the marketing and buying centre } \\
\text { which 83 Cash } \\
\text { and Carry) }\end{array}$ & $\begin{array}{l}\text { Agorà Network, Acqua \& Sapone, Sun and Aspiag Service (http://www.selexgc.it//). } \\
\text { ESD Italia is partner of the international centre EMD, European Marketing } \\
\text { Distribution, the greatest European buying centre. Making significant agreements with } \\
\text { big international industries and research of common supply sources of private label } \\
\text { products is its core activities, aimed at developing synergies and economies of scale. }\end{array}$ \\
\hline
\end{tabular}

Source: Coop, Undicesimo Rapporto Sociale Nazionale della Cooperazione di Consumatori, 2014; Coop, Decimo Rapporto Sociale Nazionale della Cooperazione di Consumatori, 2013; Coop, Nono Rapporto Sociale Nazionale della Cooperazione di Consumatori, 2012; Conad, Annual Report, 2015, 2014, 2013, 2012; Selex, Bilancio Sociale, 2014, 2013.

Also new technologies are managed jointly (i.e. with manufacturers and/or other retailers) to increase both quality and value of business services. In fact, as far as logistics functions are concerned (e.g. transport, storage, maintenance, etc.), the use of technologies and common standards as well as the establishment of communication infrastructures (e.g. EDI and EAN) has not only improved product physical flows, but has also made possible a greater integration and coordination between different distribution channels and all the partners involved in this process.

For example, technologies managed in a shared perspective has allowed retailers to efficiently organise product flows through a number of logistics procedures such as cross-docking, multi-drop, multi-pick, and multi-drop/multi-pick combination.

Specifically, by cross-docking we mean a logistic solution relying on a distribution docking terminal with two sides, one inbound and the other one outbound, where products from different manufacturers or suppliers are unloaded from inbound trucks and loaded directly into outbound trucks to be delivered to distribution centers or retail stores with little or no storage time involved ${ }^{3}$. Instead, multi-drop transport does not require a docking terminal because a manufacturer simply groups together orders made by multiple retailers, which will then be delivered by the same means of transport to stores located in the same geographical area. Likewise, multi-pick transport does not require the presence of a docking terminal since it involves picking up products from multiple manufacturers in neighboring areas and transporting them to a single point of delivery. A more recent evolution of these transport modes is the multi-drop/multi-pick combination, which sets up full truckloads of products coming from various manufacturers before shipping them to a number of retailers. Thanks to the use of technologies and consequently vehicle load capacity saturation, supply chain synchronisation, and redundancy of docking terminals, this logistic solution can reduce significantly distribution costs.

Many large-scale retailers have also implemented methodologies such as CRP, $\mathrm{CPFR}$, and $\mathrm{OSA}^{4}$ to limit supply chain costs and improve the efficiency of business activities. Others have adopted radio-frequency identification technologies (RFID). Finally, other examples of cutting-edge methodologies employed by large-scale retailers to improve business function management, particularly with regard to procurement, include: e-procurement, e-sourcing, and reverse action, all activities involving web-based supply chain management through digital platforms (emarket) to simplify interaction between companies. 


\subsection{Product/Service Range Restructuring and Adjustment of the Retailing Mix}

The current global economic crisis has deeply changed consumer consumption and buying behaviors. Diminished household incomes, decreased purchase frequency, reduction of purchased quantities along with increasingly careful selection of products and postponement of non-essential purchases are all typical factors qualifying today's consumer purchasing patterns. Consequently, consumers strive to select points of sale in relation to product-price-service advantages offered by a retailer at any given time. Indeed, the centerpiece of a retailer's offer is represented by its product range, which is complemented and enhanced, especially at the moment of purchase, by a number of other related services such as pre-sale, access, post-sale, and during-sale services. Thus, consumer demand for products and store selection strictly depends on those contingent factors that determine the purchase, such as hierarchy of consumer needs, nature of the products to be purchased, and moments and circumstances of the purchase.

It is therefore essential for large-scale retailers to determine real consumer needs in order to organise their offer accordingly through aggregation and dynamic management of its product range and related services as well as of the various levers of the retailing mix. Thanks to a clever aggregation strategy, which is the result of a carefully planned product portfolio, retailers can showcase their products and services in a temporary and differentiated fashion, which allows them to optimise the availability of certain products/services in stores where a high purchasing volume is expected only at certain times. "A careful consumer buying trend analysis" followed by a clever product display can help retailers optimise parallel and complementary purchases, which will ultimately increase consumer loyalty and favor future sales. In this regard, large-scale retailers, together with manufacturers, have heavily invested in the development of technologically advanced systems of classic and shared $\mathrm{CRM}^{5}$. Thanks to these systems, companies can share information about consumer buying behaviors not only at the single category level, but also at the cross-category level, which, in turn, will foster longlasting consumer relationships.

The development of cashiers' OCR systems as well as fidelity cards and/or coalition cards has allowed retailers to manage a high volume of detailed information on their customers. This information is then analysed together with other data obtained through classical methods (e.g. ads, interviews, marketing research, etc.) and, most importantly, through an array of cutting-edge tools and techniques. These innovative tools and techniques are deemed essential for offer restructuring because they not only enable companies to collect information on consumers in each specific store so that they can meet consumer needs by offering customised products, but also allow retailers to discover unmet consumer needs, which otherwise would pass unnoticed.

Such array of tools and techniques constitutes an important part of the in-store communication management system, which includes the following:

- Promotion and customised discounts: promotional operations such as discounts, which are usually reserved to fidelity card owners; they can be applied to a number of products chosen by consumers while shopping (e.g. 20 stickers give right to a discount of $30 \%$ ). On the one hand, only the consumer decides which 
product to discount. On the other hand, the retailer can customise future product promotions through purchase choice analysis;

- electronic couponing: customised coupons that promote specific products/brands easily obtainable by consumers with receipts of purchase. In turn, coupon-use analysis allows companies to examine price/product choices of a specific market segment or customer;

- electronic kiosks: special tactile devices located in specific store areas providing information on products/brands. In addition, these devices can issue orders, print coupons for special offers, and sometimes "create" tailor-made products by grouping products or spare parts available at the store. Upon collecting such valuable information on consumer needs, retailers can develop new value propositions;

- Personal Shopping Assistant (PSA) and in-store self-scanning: small tablets clipped to shopping carts that can be used by consumers as a "guide" while shopping. The PSA can recommend guided tours in the retail store, drawing attention to products and special offers within the store area the customer is visiting. In-store self-scanning is achieved through a portable scanner that can read bar codes of the products chosen by the consumer. Such technology provides a running total of the shopping and enables consumers to save their list of purchases while retailers can provide consumers with details of store products, brands, and promotions. In general, all of the above-mentioned technologies allow retailers to better understand consumer buying behaviors with regard to those products that have been either included or excluded from a purchase list;

- virtual fitting rooms: they are big monitors in non-food store areas, which enable shoppers to virtually try clothes on. This way, shoppers can visualise how a piece of clothing might look on them by looking at virtual screenshots taken from different angles. There are many kinds of virtual fitting rooms and all of them allow consumers to ask for details, matches, and suggestions on products (e.g. colors, sizes, price alternatives, store availability, delivery time in case of out-of-stock, etc.). Also in this case, the analysis of queries represents a valuable source of information on consumer preferences.

A careful interpretation of consumers buying habits and trends then allows retailers to manage efficiently their product/service range, often renewed by mixing together leader, follower, domestic, and local brands (with corresponding price variations) as well as commercial services and private labels (Tables 5, 6).

Table 5: Private Label Portfolio and Services ${ }^{6}$ of the three Largest Global Retailers Ranked by Revenue

\begin{tabular}{|c|c|c|}
\hline & Private label portfolio & $\begin{array}{l}\text { Services (focus on fuel and } \\
\text { pharmaceutical offer) }\end{array}$ \\
\hline Walmart & $\begin{array}{l}\text { Walmart private label portfolio is } \\
\text { extensive and adapts to assortment of } \\
\text { different retail formats and store } \\
\text { brands. Indeed Walmart International } \\
\text { works with different store brands } \\
\text { depending on geographical areas. For } \\
\text { example in Africa some of the } \\
\text { proposed store brands are the } \\
\text { following: Builders Warehouse, } \\
\text { Builders Express, Builders Trade } \\
\text { Depot, Builders Superstore, Makro, }\end{array}$ & $\begin{array}{l}\text { There are many services offered by } \\
\text { Walmart to complete the food and non-food } \\
\text { offer. The company offers financial } \\
\text { products/services, tech support, photo services, } \\
\text { insurance products/services, ecc. Walmart has } \\
\text { also developed its offer in specific markets such } \\
\text { as fuel and pharmaceuticals. For example, } \\
\text { consumers appreciate the offer of some format } \\
\text { like Walmart Neighborhood Markets, for their } \\
\text { offer variety which generally includes fresh } \\
\text { food, e-commerce order pickup, pharmacy and }\end{array}$ \\
\hline
\end{tabular}




\begin{tabular}{|c|c|c|}
\hline & $\begin{array}{l}\text { The Fruitspot, DionWired, Game, } \\
\text { Jumbo Cash \& Carry, CBW and } \\
\text { Trident, Cambridge and Rhino, Shield; } \\
\text { in Argentine: Changomas, Mi } \\
\text { Changomas, Changomas Express, } \\
\text { Walmart Supermarkets and } \\
\text { Supercenters; in Brazil: TodoDia, } \\
\text { Mercadorama, Nacional, Maxxi } \\
\text { Atacado, BIG, Bompreco, Hiper } \\
\text { Bompreco, Walmart, Sam's Club; in } \\
\text { India: Best Price Modern Wholesale; } \\
\text { in Mexico: Superama, Walmart } \\
\text { Hypermarket Stores, Bodega Aurrera, } \\
\text { Sam's Club; in UK: Asda } \\
\text { Supercentres, Asda Superstores, } \\
\text { Asda Supermarkets, Asda Living. For } \\
\text { example, ASDA private label portfolio } \\
\text { consists of the following lines: Extra } \\
\text { Special, Chosen by you, Butcher's } \\
\text { selection, Smart Price; Asda also has a } \\
\text { number of non-food private label: the } \\
\text { three principal brands are George, } \\
\text { Elegant Living, Little Angels (ASDA, } \\
\text { Our business @ Asda, October 7). }\end{array}$ & $\begin{array}{l}\text { fuel with an assortment that also includes } \\
\text { biofuels - the supply of fuel is also offered by } \\
\text { store brands belonging to the Walmart group: } \\
\text { ASDA, for example, sells fuel at ASDA Petrol } \\
\text { Filling stations. } \\
\text { The offer of health products/services } \\
\text { includes pharmaceutical products - the range } \\
\text { is wide and consists of drug brands, generics } \\
\text { and numerous products for wellness and } \\
\text { personal care - and provides the ability to } \\
\text { manage prescriptions online; the company also } \\
\text { offers some pharmacy services (e.g. drug info \& } \\
\text { price plans, mobile pharmacy app, home } \\
\text { delivery, specialty pharmacy, pet medications, } \\
\text { smart rx disposal) and health services, as clinic } \\
\text { services, wellness center, flu \& immunisations } \\
\text { and vision centers. }\end{array}$ \\
\hline Carrefour & $\begin{array}{l}\text { Carrefour offers a wide range of } \\
\text { private label products; some of these } \\
\text { are common to several countries; other } \\
\text { private label products are offered only } \\
\text { in certain geographical areas. The } \\
\text { assortment of private label is often } \\
\text { subject to innovation to meet the needs } \\
\text { of variously localised consumers. } \\
\text { In Italy, for example, the range of } \\
\text { private label products is constantly } \\
\text { growing; in particular the private label } \\
\text { portfolio consists of the following } \\
\text { lines: Carrefour BIO, Carrefour KIDS, } \\
\text { Prodotti Carrefour, Carrefour Baby, } \\
\text { Selection Carrefour, Carrefour } \\
\text { Viversano, No Gluten, Carrefour } \\
\text { Discount, TEX, TEX home. An } \\
\text { additional example is represented by } \\
\text { the offer of Carrefour private label } \\
\text { products in France as follows: les } \\
\text { produits Carrefour, les Produits Blancs, } \\
\text { Bon app' Carrefour, Carrefour Baby, } \\
\text { Carrefour Kids, Carrefour Sélection, } \\
\text { Carrefour No Gluten, Carrefour BIO, } \\
\text { Carrefour Veggie, Reflets de France, } \\
\text { Filière Qualité Carrefour, Etiquetage } \\
\text { "Nourri sans OGM" (<0,9\%), } \\
\text { Carrefour EcoPlanet, Les Cosmétiques } \\
\text { Design Paris, TEX, POSS. }\end{array}$ & $\begin{array}{l}\text { In addition to a broad selection of food and } \\
\text { non-food products, Carrefour offers its } \\
\text { customers a wide range of convenience } \\
\text { services. Financial and insurance services - } \\
\text { starting from } 2013 \text { Carrefour offers its } \\
\text { customers financing, savings and insurance } \\
\text { solutions at } 930 \text { agencies and financial service } \\
\text { stands around the world, - travel services - } \\
\text { more than } 400,000 \text { customers in France go on } \\
\text { holiday with Carrefour Voyages - leisure } \\
\text { services, photo services, are just some of the } \\
\text { services offered by Carrefour. As for the fuel, } \\
\text { the firm has heavily invested in several } \\
\text { countries for the development of refueling } \\
\text { stations located both near supermarkets and } \\
\text { hypermarkets both in areas far from the stores. } \\
\text { For instance, in France there are } 1,400 \text { petrol } \\
\text { stations with an assortment generally composed } \\
\text { of diesel, premium diesel, gasoline SP } 95 \text {, } \\
\text { gasoline SP } 98 \text {, biofuel SP95-E10, Le } \\
\text { superéthanol E85 and GPL. The company is } \\
\text { also engaged in the sale of drugs that usually } \\
\text { takes place in pharmacies and drugstores with } \\
\text { different assortments depending on the drug } \\
\text { laws that distinguish the different countries } \\
\text { where it operates. For example in France there } \\
\text { are } 120 \text { drugstores with a wide range of health, } \\
\text { personal care and beauty products/services. }\end{array}$ \\
\hline Kroger & $\begin{array}{l}\text { Corporate brands still remain a } \\
\text { strong competitive advantage for } \\
\text { Kroger. In this regard, the Kroger } \\
\text { private label portfolio is vast and often } \\
\text { renovated with attention to quality and } \\
\text { changes in consumer needs. } \\
\text { Specifically, the portfolio includes the } \\
\text { following corporate brands (Kroger, } \\
\text { The Kroger Co. Fact Book, 2014): } \\
\text { Kroger, Private Selection, Simple } \\
\text { Truth, Simple Truth Organic, P\$T..., } \\
\text { Check This Out... and Heritage Farm, } \\
\text { Comforts for Baby, Big K, and Pet } \\
\text { Pride. Kroger manufacture } 40 \% \text { of its } \\
\text { corporate brands ( } 37 \text { manufacturing } \\
\text { plants) that closed out the year } 2014 \\
\text { with strong share numbers: } 25.5 \% \\
\text { sales dollars and } 27.1 \% \text { units sold } \\
\text { (excluding pharmacy and fuel). }\end{array}$ & $\begin{array}{l}\text { Kroger is the fifth-largest pharmacy } \\
\text { operator in the United States in number of } \\
\text { locations, operating retail pharmacies in } 2,111 \\
\text { food stores; Kroger pharmacists filled almost } \\
175 \text { million prescriptions at a retail value of } \\
\text { approximately } \$ 9.0 \text { billion (Kroger, The Kroger } \\
\text { Co. Fact Book, 2014). Kroger pharmaceutical } \\
\text { and health services include: vaccinations, } \\
\text { medication therapy management, and a variety } \\
\text { of health screenings. In addition, many of } \\
\text { pharmacies offer more intensive education and } \\
\text { management programs such as diabetes and } \\
\text { heart healthy coaching, diabetes self- } \\
\text { management education, fitness, nutrition and } \\
\text { weight management, and smoking cessation. } \\
\text { Kroger offer also The Little Clinic (148 Clinics) } \\
\text { that operates in nine states under the Kroger, } \\
\text { King Soopers, Fry's and JayC banners (Kroger, } \\
\text { The Kroger Co. Fact Book, 2014). As for the } \\
\text { supply of fuel, Kroger typical supermarket fuel } \\
\text { center consists of three to nine multi-product } \\
\text { dispensers, and an } 8 \text { ' x 12' kiosk from which } \\
\text { cigarettes, soft drinks, snacks, candy and } \\
\text { miscellaneous automotive-related products are }\end{array}$ \\
\hline
\end{tabular}




\begin{tabular}{|l|l|l|}
\hline & $\begin{array}{l}\text { sold. At year-end 2014, Kroger's retail fuel } \\
\text { operations included 1,330 supermarket fuel } \\
\text { centers in 31 states and 723 convenience stores } \\
\text { that sell fuel. }\end{array}$ \\
\hline
\end{tabular}

Source: Walmart Annual Report, 2012, 2013, 2014; ASDA, Our business @ Asda, October 7, 2013; Carrefour Annual Activity and Responsible Commitment Report, 2012, 2013, 2014; Kroger, The Kroger Co. Fact Book, 2012, 2013, 2014.

Table 6: Private Label Portfolio Services ${ }^{7}$ of the Three Largest Italian Retailers Ranked by Turnover

\begin{tabular}{|c|c|c|}
\hline & Private label portfolio & $\begin{array}{c}\text { Services (focus on fuel and pharmaceutical } \\
\text { offer) }\end{array}$ \\
\hline Coop & $\begin{array}{l}\text { Private label products constitute the } \\
\text { ultimate goal of Coop's cooperative } \\
\text { mission. To this end, each Coop } \\
\text { private label product must be } \\
\text { affordable, good, safe, ethical, and } \\
\text { environmentally friendly. In 2014, } \\
\text { Coop Italy invested } 9 \text { million euros } \\
\text { for the development and control of its } \\
\text { private label products, which now } \\
\text { total to an amount of } 4,012 \text { items ( } 109 \\
\text { more than in 2013); total sales } \\
\text { increased by almost } 2.7 \% \text { compared } \\
\text { to } 2013 \text {. With a } 26.3 \% \text { share in the } \\
\text { total FMCG industry, Coop products } \\
\text { account for about } 22 \% \text { of private label } \\
\text { products sold by large retailers in Italy } \\
\text { in both hypermarkets and } \\
\text { supermarkets. The overall sales } \\
\text { turnover of these private label } \\
\text { products, which are often upgraded to } \\
\text { better meet consumer needs, is of } \\
\text { about } 2.8 \text { billion euros and it is } \\
\text { distributed among the following } \\
\text { product lines: Tutela (2,735*), Vivi } \\
\text { Verde (551*), Fiorfiore (396*), } \\
\left.\text { Solidal ( } 45 *) \text { Bene.sì ( } 80^{*}\right) \text {, Club } 4- \\
10(19 *) \text { Crescendo (131*) and Coop } \\
\& \text { Go (55*) (Coop, Undicesimo } \\
\text { Rapporto Sociale Nazionale della } \\
\text { Cooperazione di Consumatori, } 2014) \text {. } \\
* \text { number of items per product line }\end{array}$ & $\begin{array}{l}\text { In the recent past, Coop has diversified its } \\
\text { product range, which now includes services } \\
\text { never offered before by traditional retailers. } \\
\text { Specifically, in Coop supermarkets, } \\
\text { hypermarkets, or in dedicated specific areas it } \\
\text { can now be found a plethora of new services } \\
\text { such as Coop libraries - the network of } \\
\text { libraries is spread over } 11 \text { Italian regions and } \\
\text { consists of } 39 \text { stores, } 24 \text { of which are located } \\
\text { inside commercial centers (malls), } 10 \text { in Eataly } \\
\text { stores, and the remaining } 5 \text { in various historical } \\
\text { centers - Coop Voce - in } 2014 \text { over } 230,000 \\
\text { new CoopVoce telephone lines were activated, } \\
\text { for a staggering total of about } 1.4 \text { million } \\
\text { activations since service inception - travel } \\
\text { agencies - Coop operates in the tourism sector } \\
\text { through two travel agencies: Robinture and } \\
\text { New Planetarium, present in some Italian } \\
\text { regions. With regard to gasoline supply, the } \\
\text { fuel network, which operates under the brand } \\
\text { names Coop or Enercoop, consists of } 20 \text { plants } \\
\text { providing } 194 \text { million liters of fuel (diesel and } \\
\text { gasoline) and } 18 \text { million liters of LPG (present } \\
\text { in } 13 \text { of them). Methane gas is delivered in } 4 \text { of } \\
\text { these facilities (Coop, Undicesimo Rapporto } \\
\text { Sociale Nazionale della Cooperazione di } \\
\text { Consumatori, 2014). Regarding the } \\
\text { pharmaceutical market, there are } 129 \text { active } \\
\text { pharmacy corners, named Coop Salute, } 110 \text { of } \\
\text { which are located in major hypermarkets, and } \\
28 \text { in supermarkets. The assortment of these } \\
\text { pharmacy corners, consists of approximately } \\
2,900 \text { products, which include about } 2,300 \\
\text { parapharmaceuticals and several other Coop } \\
\text { branded pharmaceuticals, such as } \\
\text { acetylsalicylic acid + ascorbic acid, } \\
\text { paracetamol, calefred, carbocysteine syrup, } \\
\text { acetylcysteine, and flurbiprofen mouthwash } \\
\text { and spray. (Coop, Undicesimo Rapporto } \\
\text { Sociale Nazionale della Cooperazione di } \\
\text { Consumatori, } 2014 \text { ). }\end{array}$ \\
\hline Conad & $\begin{array}{l}\text { Its private label is vital to the } \\
\text { development of Conad's sales } \\
\text { network and brand loyalty. In } 2014 \text {, } \\
\text { Conad's sale volumes grew by } 3.9 \% \\
\text { over the previous year, generating } \\
\text { revenues of } 2.55 \text { billion euros. This } \\
\text { excellent performance was also due to } \\
\text { the launch of the campaign "Low \& } \\
\text { Fixed", which offered hundreds of } \\
\text { products at affordable and fixed prices } \\
\text { throughout the year. Conad private } \\
\text { label offers a wide range of products }\end{array}$ & $\begin{array}{l}\text { Conad has been able to diversify its } \\
\text { traditional core products thanks to the offer of a } \\
\text { wide range of services/products such as optical } \\
\text { services, fuel supply and pharmaceutical } \\
\text { products/services. In 2014, } 16 \text { new optical } \\
\text { corners, named Ottico Conad, were opened in } \\
\text { supermarkets and hypermarkets in various } \\
\text { Italian regions offering an assortment of over } \\
800 \text { optical frames and sunglasses along with } \\
\text { opticians that could provide professional } \\
\text { advice. As for fuel supply, since the first Conad } \\
\text { gas station opened in 2005, the fuel offer has }\end{array}$ \\
\hline
\end{tabular}




\begin{tabular}{|c|c|c|}
\hline & $\begin{array}{l}\text { divided into five brands constantly } \\
\text { innovated to meet the ever-changing } \\
\text { consumer needs, and consists of a } \\
\text { total of } 2,949 \text { items divided as } \\
\text { follows: 2,101 Conad, 500 Conad } \\
\text { Percorso Qualità, 53 Conad Il } \\
\text { Biologico, 245 Sapori \& Dintorni } \\
\text { Conad, 50 Creazioni d'Italia (Conad, } \\
\text { Annual Report, 2014). }\end{array}$ & $\begin{array}{l}\text { grown steadily resulting in the construction of } \\
28 \text { new plants, each of which boasts an average } \\
\text { annual throughput of about } 8.3 \text { million liters. } \\
\text { The number of customers served during the } \\
\text { year } 2014 \text { amounted to approximately } 11 \\
\text { million. Conad fuel distributors have also } \\
\text { increased their fuel throughput by } 12 \text { percent } \\
\text { compared to that generated by all opened plants } \\
\text { until } 2013 \text {. Lastly, as of year } 2014 \text {, Conad } \\
\text { parapharmacies amount to } 82 \text { and are located in } \\
\text { Conad's main hypermarkets, superstores and } \\
\text { supermarkets. Their product range consists of } \\
\text { about } 5,000 \text { products, of which more than } 500 \\
\text { are over-the-counter (OTC) drugs, not subject } \\
\text { to medical prescription. The product range } \\
\text { includes also a variety of homeopathic and } \\
\text { veterinary drugs, subject or not to medical } \\
\text { prescription, thousands of products for personal } \\
\text { hygiene, and a wide selection of food } \\
\text { supplements and natural remedies for the needs } \\
\text { of the whole family. The turnover of Conad } \\
\text { pharmaceutical sector is of about } 45 \text { million } \\
\text { euros, with the pharmaceuticals accounting for } \\
30 \% \text { percent of total revenues (Conad, Annual } \\
\text { Report, 2014). }\end{array}$ \\
\hline Selex & $\begin{array}{l}\text { Private label products amount to } \\
\text { more than 5,000 items grouped under } \\
\text { the following brands: Selex ( } 3,000 \\
\text { items distributed among the following } \\
\text { specialised product lines: Natura } \\
\text { Chiama Selex, Vivi Bene Selex, Vivi } \\
\text { Bene Selex Senza Glutine, Primi Anni } \\
\text { Selex, and Saper di Sapori), Sù and } \\
\text { Vanto (600 items), Vale (more than } \\
1,100 \text { items distributed among the } \\
\text { following specialised product lines: } \\
\text { Vale Natura in Tavola di Filiera } \\
\text { Controllata, Vale Le Specialità, Vale } \\
\text { Natura in Tavola Bio), and other } \\
\text { brands such as Prodotto Risparmio, } \\
\text { Atmosfera \& Benessere, Le Vie } \\
\text { dell'Uva, Le Bontà del Pasticciere, } \\
\text { Storie di Gastronomia, and, } \\
\text { CasaxCasa (Selex Gruppo } \\
\text { Commerciale, 2014). }\end{array}$ & $\begin{array}{l}\text { The Selex Group offers several } \\
\text { services/products unrelated to the core business } \\
\text { of its various associated enterprises. However, } \\
\text { a detailed list of these additional } \\
\text { services/products is not easy to make as many } \\
\text { of the associated companies develop a specific } \\
\text { offer and, as already mentioned above, the } \\
\text { group has a multi-store brand policy. These } \\
\text { brands are as follows: Famila, A\&O, C+C, } \\
\text { Galassia, Emisfero, Bigstore, Alì Supermercati, } \\
\text { EMI, Supermercati Dock, Superconti, Sì Con } \\
\text { Te, Mercatò Superstore, Maxisconto } \\
\text { Supermercati, Pan, Futura, Elite, Superdì, Pick } \\
\text { Up, Urrà Discount, Dpiù, harDis, } \\
\text { l'abbondanza, Ok Market. The new entry "Il } \\
\text { Gigante" has allowed the Group to expand the } \\
\text { number of its services by offering fuel at } \\
\text { competitive prices. }\end{array}$ \\
\hline
\end{tabular}

Source: Coop, Undicesimo Rapporto Sociale Nazionale della Cooperazione di Consumatori, 2014; Conad, Annual Report, 2014; Selex, Bilancio Sociale, 2014.

In particular, careful management of private label policies seems to represent a critical aspect of retail-growth policies. Indeed, over the last few years, retailers have been investing heavily in the structural strengthening of their core and noncore (e.g. fuel and pharmaceutical sales) (Riboldazzi, 2010) private label products (Tables 5, 6). In today's market, private labels are used by companies to gain a competitive advantage over the competition as they can enhance the retailer's negotiation power with suppliers, promote diversification, and strengthen both brand image and customer loyalty, thereby improving the profitability and competitive position of the company.

In this regard, the majority of large-scale retailers offers a deep assortment of private label products often subject to market-driven innovation (Brondoni, 2009; Brondoni, Corniani, Riboldazzi, 2013) characterised by different price positioning (from premium to low price) to meet the needs of different types of consumers and/or different types of needs coming from the same market segment. 


\subsection{Reconfiguration of Retail Format Portfolio and Multi-Channel Policies}

Large-scale retailers generally manage different retail formats (e.g. supermarkets, hypermarkets, specialty stores, etc.) according to the place where they operate in order to maintain a balance between corporate growth and profitability of the asset portfolio (Tables 7, 8).

In recent years, a number of factors ${ }^{8}$ have led many large-scale retailers to reconfigure their formats and distribution channels to support sales.

Specifically, we can observe a general propensity to reduce the number of format managed with investments in high-profitability formats; in particular, we can observe the development of convenience stores and/or discount stores and the reduction of openings and reconfiguration of hypermarkets.

Convenience stores are generally characterised by urban localisation, limited sales areas, extended opening hours, limited food or drink assortment generally destined to household consumption. Indeed, this format aims at meeting mainly marginal and integrative consumer needs as opposed to those met by other grocery store formats; hence, convenience stores represent a reference point for unexpected and first-necessity purchases, which complement the sales made in larger grocery stores. In many cases, large-scale retailers have also opened "high quality" convenience stores, which can generate high-profit margins by selling private label premium assortments. Likewise, discount stores have recently managed to successfully increase business growth by opening new points of sale positioned in the medium/low price range. In contrast, when we look at the business performance of hypermarkets, we can only observe a gradual but significant decrease in both sales and growth levels. To counteract this negative trend, a number of large-scale retailers have renewed their hypermarkets to meet "high quality" and complementary demands with respect to those met by other sale formats. Particularly, many hypermarkets have renewed their offer by including high valueadded services (e.g. increased number of checkout counters, self-service checkout counters, technological stations and food areas, etc.) and by rationalizing assortment aggregation. In order to maintain a balance between development and profitability, many large-scale retailers have also invested in the development of special formats and distribution channels able to satisfy growing levels of demand (Tables 7, 8); they are for example online channels, virtual supermarkets and sustainable supermarkets.

Table 7: Traditional Stores and some Innovative Stores/Channels (Focus on ECommerce) of the three Largest Global Retailers Ranked by Revenue

\begin{tabular}{|l|l|l|}
\hline Walmart & Traditional stores/format and locations & \multicolumn{1}{c|}{ E-commerce } \\
\hline Walmart format portfolio is composed as follow: & $\begin{array}{l}\text { Walmart is heavily investing to gain market } \\
\text { share with respect to e-commerce. The company's } \\
\text { objectives are: provide more personalised and } \\
\text { relevant shopping options; offer a broad product } \\
\text { assortment; provide the best possible shopping } \\
\text { experience online; and deliver merchandise at the } \\
\text { lowest possible cost to customers when and where } \\
\text { they want it. (Walmart, Annual Report, 2013) } \\
\text { In the U.S., the assortment of walmart.com } \\
\text { consists of more than 5 million SKUs and } \\
\text { convenient delivery options to customers home or } \\
\text { through Site to Store. Walmart develops their } \\
\text { activity on internet also in others countries than }\end{array}$ \\
$\begin{array}{l}508 \text { Discount Stores } \\
407 \text { Neighborhood Markets }\end{array}$
\end{tabular}




\begin{tabular}{|c|c|c|}
\hline & $\begin{array}{l}632 \text { Sam's Club } \\
\text { These stores are located in the following States or } \\
\text { Territory: Alabama, Arizona, Arkansas, California, } \\
\text { Colorado, Connecticut, Delaware, Florida, } \\
\text { Georgia, Hawaii, Idaho, Illinois, Indiana, Iowa, } \\
\text { Kansas, Kentucky, Louisiana, Maine, Maryland, } \\
\text { Massachusetts, Michigan, Minnesota, Mississippi, } \\
\text { Missouri, Montana, Nebraska, Nevada, New } \\
\text { Hampshire, New Jersey, New Mexico, New York, } \\
\text { North Carolina, North Dakota, Ohio, Oklahoma, } \\
\text { Oregon, Pennsylvania, Rhode Island, South } \\
\text { Carolina, South Dakota, Tennessee, Texas, Utah, } \\
\text { Vermont, Virginia, Washington, Washington D.C, } \\
\text { West Virginia, Wisconsin, Wyoming, Puerto Rico. } \\
\text { - Walmart International } \\
5,633 \text { retail stores } \\
359 \text { wholesale stores } \\
115 \text { restaurants, drugstores and convenience stores } \\
\text { operating under varying banners } \\
\text { These stores are located in the following } \\
\text { geographic markets: Africa, Argentina, Brazil, } \\
\text { Canada, Central America, Chile, China, India, } \\
\text { Japan, Mexico, United Kingdom. }\end{array}$ & $\begin{array}{l}\text { U.S. For example, in Brazil, after a threefold } \\
\text { increase in site traffic, walmart.com consistently } \\
\text { ranks as the first or second most visited retail site. } \\
\text { In China, Walmart has invested in Yihaodian's } \\
\text { new, a more intuitive mobile app that helped } \\
\text { expand mobile transactions eightfold in one year. } \\
\text { (Walmart, Annual Report, 2014). }\end{array}$ \\
\hline Carrefour & $\begin{array}{l}\text { Carrefour manages } 10,860 \text { stores in over } 30 \\
\text { countries: } \\
\text { 1,459 hypermarkets } \\
3,115 \text { supermarkets } \\
175 \text { cash \& carry stores } \\
6,111 \text { convenience store } \\
\text { These stores are located in the following area: } \\
\text { Argentina } 572 \text { stores } \\
\text { Brazil } 258 \text { stores } \\
\text { France } 5,013 \text { stores } \\
\text { Belgium } 744 \text { stores } \\
\text { Spain } 582 \text { stores } \\
\text { Poland } 702 \text { stores } \\
\text { Romania } 174 \text { stores } \\
\text { Italy } 1,158 \text { stores } \\
\text { China } 236 \text { stores } \\
\text { Taiwan } 71 \\
\text { Other countries (in Europe, Asia, North Africa, } \\
\text { Middle East, Dominican Republic) } 1,350 .\end{array}$ & $\begin{array}{l}\text { Carrofour continues to develop e-commerce } \\
\text { and m-commerce solutions to enable its customers } \\
\text { to shop anytime and anywhere, from a laptop } \\
\text { computer, a tablet or a smartphone (Carrefour, } \\
\text { Annual Report, 2013). Customers can shop on- } \\
\text { line and have their order delivered, or collect it at } \\
\text { the store or at a drive pick-up point. In France, the } \\
\text { company offers grocery collection at nearly } 440 \\
\text { drive pick-up points, most of them in stores so that } \\
\text { customers can make additional purchases if need } \\
\text { be. Italian and Belgian customers can also use this } \\
\text { service at certain stores. (Carrefour Annual } \\
\text { Report, 2014). }\end{array}$ \\
\hline Kroger & $\begin{array}{l}\text { Kroger menages } 3,733 \text { stores: } \\
\text { 2,625 supermarkets: } \\
\text { combination stores } 2,269 \\
\text { multi-department stores } 127 \\
\text { marketplace stores } 98 \\
\text { price impact stores } 131 \\
782 \text { convenience stores } \\
326 \text { Jewelry Stores } \\
\text { The supermarket locations are the following: } \\
\text { California, Ohio, Texas, Georgia, North Carolina, } \\
\text { Indiana, Colorado, Michigan, Tennessee, Arizona, } \\
\text { Washington, Kentucky, Virginia, Kansas, Illinois, } \\
\text { Oregon, Utah, West Virginia, Nevada, Arkansas, } \\
\text { Mississippi, South Carolina, New Mexico, Idaho, } \\
\text { Maryland, Missouri, Alaska, Nebraska, Alabama, } \\
\text { Wyoming, Louisiana, Montana, Washington, D.C., } \\
\text { Delaware, Florida. }\end{array}$ & $\begin{array}{l}\text { Kroger invests in digital and omnichannel, } \\
\text { developing their websites, mobile applications, } \\
\text { using digital channel to communicate with } \\
\text { customers etc. For example, the company } \\
\text { develops Express Lane; this service is available at } \\
\text { over } 160 \text { Harris Teeter® stores, providing } \\
\text { customers with online ordering and the } \\
\text { convenience of picking up orders at their local } \\
\text { store. Customers can shop online and schedule } \\
\text { pick-up in as little as } 4 \text { hours after submitting an } \\
\text { order (Kroger, The Kroger Co. Fact Book, 2014). } \\
\text { Finally, in } 2014 \text { Kroger expanded its digital } \\
\text { capabilities by merging with Vitacost.com, a } \\
\text { leading online retailer of healthy living products } \\
\text { (Kroger, The Kroger Co. Fact Book, 2014). }\end{array}$ \\
\hline
\end{tabular}

Source: Walmart Annual Report, 2013, 2014; Carrefour Annual Activity and Responsible Commitment Report, 2013, 2014; Kroger, The Kroger Co. Fact Book, 2014. 
Table 8: Traditional Stores and some Innovative Store/Channels of the three Largest Italian Retailers Ranked by Turnover

\begin{tabular}{|c|c|c|}
\hline & $\begin{array}{c}\text { Traditional stores/format } \\
\text { and locations }\end{array}$ & Innovative store/channels \\
\hline Cоор & $\begin{array}{l}\text { Coop manages } 1,189 \\
\text { stores (formats: Ipercoop } \\
\text { hypermarkets, Coop } \\
\text { supermarkets, and other } \\
\text { smaller stores) spread in } \\
89 \text { Italian provinces and } \\
774 \text { Italian municipalities. }\end{array}$ & 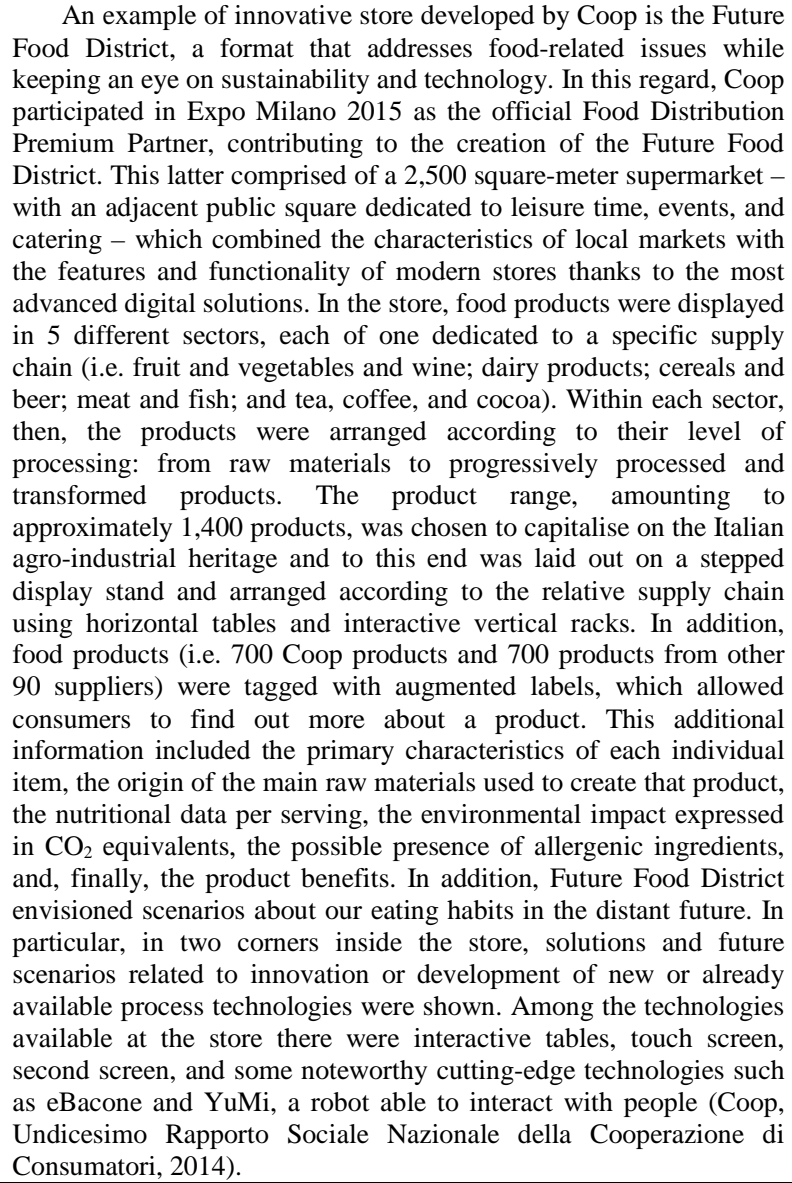 \\
\hline Conad & $\begin{array}{l}\text { Conad manages } 3,015 \\
\text { stores spread over } 108 \\
\text { Italian provinces and } \\
1,470 \text { Italian } \\
\text { municipalities; the stores } \\
\text { are divided as follows: } 25 \\
\text { Conad Hypermarkets, } 197 \\
\text { Conad Superstores, } 1,010 \\
\text { Conad Supermarkets, } 962 \\
\text { Conad City, 566 Conad } \\
\text { Margherita, } 189 \text { Discount, } \\
\text { and } 66 \text { other stores. }\end{array}$ & $\begin{array}{l}\text { An example of an innovative store format by Conad is the } \\
\text { Sapori \& Dintorni. Conad and Major stations have signed an } \\
\text { agreement for the development of the Sapori \& Dintorni format in } \\
\text { four major Italian railway stations (i.e. Roma Termini, Milano } \\
\text { Centrale, Florence S. Maria Novella and Napoli Centrale). The } \\
\text { format aims at promoting the regional Italian food excellence by } \\
\text { offering about } 225 \text { products from } 58 \text { product categories related to } \\
\text { various local gastronomic traditions. Format productivity leads the } \\
\text { market with a staggering } 21,000 \text { euros } / \mathrm{m}^{2} \text { (Conad, Annual Report, } \\
\text { 2014). }\end{array}$ \\
\hline Selex & $\begin{array}{lr}\text { Selex manages } & 2,549 \\
\text { stores spread in all Italian } \\
\text { regions divided in } 21 \\
\text { hypermarkets, } \quad 60 \\
\text { superstores } \quad \text { and } \\
\text { minihypers, } 272 \text { integrated } \\
\text { supermarkets, } \quad 753 \\
\text { supermarkets, } \quad 422 \\
\text { superettes, 449 discount } \\
\text { stores, 482 minimarkets, } \\
\text { and } 90 \text { Cash and Carry. }\end{array}$ & $\begin{array}{l}\text { An example of an innovative store format by Selex is } \\
\text { represented by its various eco-friendly stores. In particular, the stores } \\
\text { of Piazzola sul Brenta and Terranegra (Padova), Camponogara and } \\
\text { Cavarzere (Venice), were built according to criteria based on the } \\
\text { concept of sustainability; the stores are indeed equipped with } \\
\text { photovoltaic systems for the production of clean energy - in } 2013 \text {, } \\
\text { they generated } 295,000 \mathrm{kWh} \text { of clean energy - which resulted in a } \\
\text { significant reduction in } \mathrm{CO}_{2} \text { emissions - in } 2013 \text {, a total of } 136,288 \\
\mathrm{~kg} \text { of } \mathrm{CO}_{2} \text {, equivalent to } 56 \text { tons of oil, did not enter the atmosphere } \\
- \text { as well as of refrigerators capable of ensuring optimum } \\
\text { refrigeration but reduced energy consumption. }\end{array}$ \\
\hline
\end{tabular}

Source: Coop, Undicesimo Rapporto Sociale Nazionale della Cooperazione di Consumatori, 2014; Conad, Annual Report, 2014; Selex, Bilancio Sociale, 2013, 2014. 
In this regard, the development of internet and web-based technologies has allowed retailers to support their traditional sales with on-line sales, thereby combining the advantages deriving from the availability of sales surface in brickand-mortar stores with those opportunities arising from the lack of temporal and spatial constraints typical of e-commerce.

A particular "sales strategy" exploiting web-based technology is the so-called virtual store, which in some countries has been successful in targeting those techsavy consumers with only a limited time for shopping. Specifically, virtual stores are virtual points of sale made up of backlit panels, which display merchandise in public areas (e.g. railway stations, tube stations, and airports) ${ }^{9}$. Every product is generally associated with a QrCode, which, if scanned with a smart phone, provides valuable information on the product and also allow the consumer to directly make the purchase as well as to choose the place and date of delivery. Many companies have developed successful virtual stores thanks to efficient logistic systems often managed in partnership with specialised operators - for example Tesco Home Plus in Korea, the French retailer Carrefour, and the Belgian chain Delhaize.

Finally, in recent years, large-scale retailers have opened an increasingly larger number of eco-friendly stores to foster sustainable retail development. Indeed, there has been a growing awareness of sustainability and global responsibility (Salvioni, 2003) among large-scale retailers as a way of gaining broad consensus among stakeholders, while ensuring resources necessary for continuous business development. Eco-friendly stores are retail stores built with new techniques and methods able to reduce consumption of natural resources during the whole life cycle of the building. Such stores are built to reduce their environmental impact taking into account the following aspects: use, management, and disposal of water; water consumption; water reutilisation; use of alternative or renewable energy sources; monitoring of building energy performance; use of eco-friendly materials, and so on. Moreover, eco-friendly stores management generally relies on the implementation of business functions (e.g. procurement, transport, etc.) that need to be consistent with environmentally friendly policies specifically concerning assortment management. To this end, sustainable store offer a number of ecofriendly private and non-private label products such as organic products ${ }^{10}$, green products $^{11}$, locally grown products ${ }^{12}$, or unpackaged products ${ }^{13}$, increasingly more present in different categories of large-scale retail assortment. Some companies have also adopted, especially for private label products, green packaging to limit pollution and convey their commitment to environmental protection. Green assortment management is often certified by voluntary certifications such as Ecolabel (CE regulation n. 66/2010), Eco-Management and Audit Scheme (EMAS), and Environmental Product Declaration (EPD).

The three "new development policies" mentioned above are tightly linked and overlap with "basic development policies"; indeed, the adjustment of product/service range and retailing mix, as well as the reconfiguration of retail format portfolio determine changes in commercial functions thereby triggering a circle of business development. 


\section{Conclusions}

The growing complexity of today's business systems has led to a substantial modification of retailers' development policies. In particular, in recent years, largescale retailers have found ways to overcome the emergence of increasingly severe constraints on retail business development by devising new development trajectories aimed at maintaining or strengthening their competitive positions.

Our analysis of business activities of some of the major global (Walmart, Carrefour, Kroger) and Italian (Coop, Conad, Selex) large-scale retailers reveals how these companies have been able to dynamically implement a synergistic set of basic development policies (see paragraph 1) strictly dependent on opportunities arising from changes in global markets. In particular, when we examine the history of retailing, it appears that large-scale retail business development has always been tightly linked to the extent of innovation in the value chain, which has become increasingly sophisticated as a result of technological progress and changes in both consumer demand and competition taking place in the market where major retailers operate. Thus, in general, growth and development of large-scale retailers goes hand in hand with innovation, which may relate to the following aspects: 1) in-store marketing (e.g. store design, merchandising, communication, technology, etc.); 2) combination of services offered in existing channels; 3) development of a new distribution channel. Obviously, product innovation in retailing cannot be achieved unless all three dimensions of innovation (e.g. product, process, and organisation) are effectively pursued.

Innovation, in recent years, has also been achieved by retailers thanks to "new development policies", which often complement each other and overlap with basic development policies. These new policies are characterised by:

1) improvement of business function efficiency to contain costs and improve business performance;

2) product/service range restructuring and adjustment of the retailing mix in order to become more efficient and effective when offering a product or service;

3) reconfiguration of the retail format portfolio and multi-channel policies as a way of satisfying consumer needs and improving business performance, all crucial aspects of stakeholder engagement and consensus building, so as to generate through resource availability continuing business development.

\section{Bibliography}

Arrigo, E. (2009). Market-Driven Management, Global Competition and Corporate Responsibility, Symphonya. Emerging Issues in Management (symphonya.unimib.it), 1, 54-70. http://dx.doi.org/10.4468/2009.1.06arrigo

ASDA. (2013). Our business @ Asda, October 7.

Bakos, Y. (2001). The Emerging Landscape for Retail E-Commerce, The Journal of Economic Perspectives, 15 (1), 69-80.

http://dx.doi.org/10.1257/jep.15.1.69

Bansal, P., \& Kilbourne, W. E. (2001). The Ecologically Sustainable Retailer, Journal of Retailing and Consumer Services, 8 (3), 139-146.

http://dx.doi.org/10.1016/S0969-6989(00)00012-6 
Basker, E., Klimek, S., \& Hoang Van, P. (2012). Supersize It: The Growth of Retail Chains and the Rise of the "Big-Box" Store, Journal of Economics \& Management Strategy, 21 (3), 541-582. http://dx.doi.org/10.1111/j.1530-9134.2012.00339.x

Brondoni, S.M. (2015). Global Networks, Outside-In Capabilities and Smart Innovation, Symphonya. Emerging Issues in Management (symphonya.unimib.it), 1, 6-21.

http://dx.doi.org/10.4468/2015.1.02brondoni

Brondoni, S.M. (2014). Global Capitalism and Sustainable Growth. From Global Products to Network Globalisation, Symphonya. Emerging Issues in Management (symphonya.unimib.it), 1, 10-31.

http://dx.doi.org/10.4468/2014.1.02brondoni

Brondoni, S.M. (2009). Market-Driven Management, Competitive Customer Value and Global Networks, Symphonya. Emerging Issues in Management (symphonya.unimib.it), 1, 8-25. http://dx.doi.org/10.4468/2009.1.02brondoni

Brondoni, S.M., Corniani, M., \& Riboldazzi, S., (2013). Global Retailers, Market-Driven Management and Innovation, International Journal of Economic Behavior, 3, 27-40.

Burt, S. (1993). Temporal Trends in the Internationalisation of British Retailing, The International Review of Retail, Distribution and Consumer Research, 3 (4), 391-410. http://dx.doi.org/10.1080/09593969300000025

Burt, S. L., Mellahi, K., Jackson, T. P., \& Sparks, L. (2002). Retail Internationalisation and Retail Failure: Issues From the Case of Marks and Spencer, The International Review of Retail, Distribution and Consumer Research, 12 (2), 191-219.

http://dx.doi.org/10.1080/09593960210127727

Burt, S. (1991). Trends in the Internationalisation of Grocery Retailing: the European Experience, The International Review of Retail, Distribution and Consumer Research, 1 (4), 487-515. http://dx.doi.org/10.1080/09593969100000005

Carrefour. (2012, 2013, 2014). Annual Activity and Responsible Commitment Report.

Conad. (2012, 2013, 2014, 2015). Annual Report.

Coop. (2012). Nono Rapporto Sociale Nazionale della Cooperazione di Consumatori.

Coop. (2013). Decimo Rapporto Sociale Nazionale della Cooperazione di Consumatori.

Coop. (2014). Undicesimo Rapporto Sociale Nazionale della Cooperazione di Consumatori.

Deloitte. (2015). Top 10 Global Retailers Show Modest Growth in 2014.

Doherty, A. M. (2007). The Internationalisation of Retailing: Factors Influencing the Choice of Franchising as a Market Entry Strategy, International Journal of Service Industry Management, 18 (2), 184-205.

http://dx.doi.org/10.1108/09564230710737826

Dupuis, M. (2000). Retail Innovation: Towards a Framework of Analysis, International EAERCD Conference on Retail Innovation, Barcelona: ESADE.

Gnecchi, F. (2009). Market-Driven Management, Market Space and Value Proposition, Symphonya. Emerging Issues in Management (symphonya.unimib.it), 2, 33-45.

http://dx.doi.org/10.4468/2009.2.04gnecchi

Goldman, A., \& Hino, H. (2005). Supermarkets vs. Traditional Retail Stores: Diagnosing the Barriers to Supermarkets' Market Share Growth in an Ethnic Minority Community, Journal of Retailing and Consumer Services, 12 (4), 273-284.

http://dx.doi.org/10.1016/j.jretconser.2004.10.002

Gripsrud, G., \& Benito, G. R. G. (2005). Internationalisation in Retailing: Modeling the Pattern of Foreign Market Entry, Journal of Business Research, 58 (12), 1672-1680.

http://dx.doi.org/10.1016/j.jbusres.2004.11.003

Gundlach, G. T., Bolumole, Y. A., Eltantawy, R. A., \& Frankel R. (2006). The Changing Landscape of Supply Chain Management, Marketing Channels of Distribution, Logistics and Purchasing, Journal of Business \& Industrial Marketing, 21 (7), 428-438. 


\section{http://dx.doi.org/10.1108/08858620610708911}

Gupta, S., \& Loulou, R. (1998). Process Innovation, Product Differentiation, and Channel Structure: Strategic Incentives in a Duopoly, Marketing Science, 17 (4), 301-316.

Hollander S. C. (1960). The Wheel of Retailing, Journal of Marketing, 25 (1), 37-42.

Kosová, R., \& Lafontaine, F. (2010). Survival and Growth in Retail and Service Industries: Evidence from Franchised Chains, The Journal of Industrial Economics, 58 (3), 542-578.

http://dx.doi.org/10.1111/j.1467 6451.2010.00431.x

Kroger. (2012, 2013, 2014). The Kroger Co. Fact Book.

Musso, F. (2010). Innovation in Marketing Channels, Symphonya. Emerging Issues in Management (symphonya.unimib.it), 1, 23-42.

http://dx.doi.org/10.4468/2010.1.04musso

Planet Retail (2015) http://www1.planetretail.net/

Riboldazzi, S. (2015). R\&D and Product Engeneering in Global Pharmaceutical Companies, Symphonya. Emerging Issues in Management (symphonya.unimib.it), 2, 57-74. http://dx.doi.org/10.4468/2015.2.05riboldazzi

Riboldazzi, S. (2010). Retail Policies in the Global Gasoline Market, Symphonya. Emerging Issues in Management (symphonya.unimib.it), 1, 86-101.

http://dx.doi.org/10.4468/2010.1.09riboldazzi

Riboldazzi, S. (2005). Global Retailers and Competitive Customer Value, Symphonya. Emerging Issue in Management (symphonya.unimib.it), 2, 77-87.

http://dx.doi.org/10.4468/2005.2.07riboldazzi

Risso, M. (2010). Large Retailers' Financial Services, Symphonya. Emerging Issues in Management (symphonya.unimib.it), 1, 65-75.

http://dx.doi.org/10.4468/2010.1.07risso

Robinson, T. M., \& Clarke-Hill, C. M. (1990). Directional Growth by European Retailers, International Journal of Retail \& Distribution Management, 18 (5).

http://dx.doi.org/10.1108/09590559010005606

Rosenbloom, B. (2004). Marketing Channels: A Management View. Mason, Ohio: Thomson South Western.

Salvioni, D. M., \& Astori, R. (2013). Sustainable Development and Global Responsibility in Corporate Governance, Symphonya. Emerging Issues in Management (symphonya.unimib.it), 1, 28-52. http://dx.doi.org/10.4468/2013.1.03salvioni.astori

Salvioni, D. M. (2008). Market-Driven Management and Corporate Governance, Symphonya. Emerging Issues in Management (symphonya.unimib.it), 2, 13-27.

http://dx.doi.org/10.4468/2008.2.02salvioni

Salvioni, D. M. (2003). Corporate Governance and Global Responsibility, Symphonya. Emerging Issues in Management (symphonya.unimib.it), 1, 2003, 44-54.

http://dx.doi.org/10.4468/2003.1.05salvioni

Selex Gruppo Commerciale. $(2013,2014)$. Bilancio Sociale.

WalMart Stores, Inc. (2015). Fact Book - Fiscal 2015.

WalMart. (2012, 2013, 2014, 2015). Annual Report.

\section{Notes}

${ }^{1}$ It should be noticed that all three companies have established a number of equity e non-equity alliances with different players to develop their activities. As example, we describe some merger and acquisition operations activated by the three retailers in various geographical area.

${ }^{2}$ It should be noted that all three companies originated from business forms of association and aggregation that are typical of cooperatives, buying groups, and voluntary unions. Specifically, 
Coop Italia is a consumer cooperative, Conad is an organization that joins retailer cooperatives, and Selex is a commercial group originally established as a voluntary union. Here, we describe buying centers established by these three retailers in order to limit costs and improve operational efficiency; nonetheless, the three groups have established a number of partnerships (e.g. franchising, cornering, shared R\&D, shared advertising, etc..) with different operators (e.g. competitors, universities, research institutes, etc.) to develop company activities in the various Italian regions.

${ }^{3}$ There are two kinds of cross-docking: 1) with platform in a retail centre and stores of one only retailer; 2) with delivery points of different retailers.

${ }^{4}$ Continuous replenishment program (CRP) gives the manufacturer the responsibility to issue the order and manage stock levels at the retail centre thanks to information given by the retailer. Collaborative planning, forecasting \& replenishment (CPFR) extends cooperation to order planning and forecast, considering the medium-long period. Optimal shelf availability (OSA) regards improvement of product availability through Out-of-Stock calculation, identification of main causes and finalization of solutions (www.indicod.ecr.it).

5 Cooperation strategy that, through a joint analysis of consumer buying behaviours, differentiation and segmentation of consumer demand, and customised product offering, helps develop a long-lasting relationship with consumers to meet their needs and generate value to manufacturers and retailers (www.indicod.ecr.it).

${ }^{6}$ By way of example, here are listed some of the services developed by the large-scale retailers.

${ }^{7}$ By way of example, here are listed some of the services developed by the large-scale retailers.

${ }^{8}$ Among the factors: change of shopping availability, population ageing, reduction of family units, food consumption changes, increasing competition of specialist category killers, etc.

${ }^{9}$ They can also be place in physical stores.

${ }^{10}$ These products combine techniques of cultivation and breeding that limit their environmental impact. In particular, their manufacturing protocols avoid all synthetic chemicals and genetically modified organisms besides reducing exploitation of natural resources and energy.

${ }^{11}$ Ecological products refer to specific items dedicated to personal and house care (e.g. detergents, light bulbs, tissues, paper towels, etc.) with a low environmental impact.

${ }^{12}$ It refers to products provided by local producers whose manufacturing plants are located near the retail stores. This close proximity allows energy savings and low $\mathrm{CO}_{2}$ emissions during transportation.

${ }^{13}$ Unpackaged products are generally sold through nozzles and dispensers placed in dedicated store corners; they have no packaging, whose disposal may cause pollution. 